\title{
OCCULT HEPATITIS B INFECTION IN HEMODIALYSIS PATIENTS INFECTED WITH HEPATITIS C VIRUS
}

\author{
By \\ Abd El-Aziz Mamdouh Mohamed Abd El-Aziz Mohamed Berbesh \\ Department of Internal Medicine -Faculty of Medicine, Al-Azhar University, Cairo, Egypt \\ Mobile: 01285328692, E-mail: abdelaziz.berbesh@yahoo.com
}

\begin{abstract}
Background: Occult hepatitis B infection (OBI) is defined as the existence of low-level HBV DNA in the serum $(<200 \mathrm{IU} / \mathrm{mL})$, cells of the lymphatic (immune) system, and/or hepatic tissue in patients with serological markers of previous infection (anti-HBc and/or anti-HBs positive) and the absence of serum HBsAg.

Objective: To evaluate the prevalence of occult hepatitis B infection among hemodialysis patients infected with Hepatitis C Virus.

Patients and Methods: Our study was conducted on 100 patients with end-stage renal disease who were positive Hepatitis C Virus undergoing regular hemodialysis from the dialysis unit related to the department of nephrology, Nasser Institute, Egypt, during the period from July to January 2018. Female ratio was |39\%|, while male ratio was $|61 \%|$, age ranged from (18-60) with mean efficient $|39.20 \pm 11.98| \cdot \mathrm{HbcIgG}$ was checked to all patients, and HBV PCR to positive HBcIgG patients.
\end{abstract}

Results: The results of our study showed that $8 \%$ of the whole samples were Positive, and $92 \%$ were negative $\mathrm{HbClgG}$ patients. From these $8 \%$ positive $\mathrm{HBcIgG}$ patients, HBV PCR was positive in only $2 \%$ patients.

Conclusion: OBI was prevalent among chronic HCV patients on regular hemodialysis. However, more precise assessment of this infection requires regular patient follow up using HBV DNA detection methods.

Key words: occult heeahtis, henodialysis.

\section{INTRODUCTION}

Egypt ranks first among countries regarding the prevalence of hepatitis $\mathrm{C}$ virus (HCV) infection (Amer et al., 2015). HBV is a double-stranded DNA virus belonging to the family Hepadnaviridae, genus Orthohepadnavirus (Datta et al., 2012).

HBV infection is classified into three categories: acute, chronic, and occult hepatitis B infection (Inoue and Tanaka, 2016).
Occult hepatitis B infection (OBI) is defined as the detection of HBV DNA in the serum or liver of individuals by precise laboratory tests in the absence of hepatitis B surface antigen ( $\mathrm{HBsAg}$ ), with or without serological markers of previous viral exposure (Raimondo et al., 2019) Possibility of infection among HD patients is increased due to their low response to $\mathrm{HBV}$ vaccination (Aghakhani et al., 2010).

Prevalence rates of OBI are influenced by several factors, including $\mathrm{HBV}$ 
endemicity and subtypes, patient characteristics, the sensitivity of diagnostic techniques, the type and number of samples, and the implementation of infection prevention and control (Raimondo and Pollicino, 2016).

In a study from Japan, OHB appeared to be an important risk factor in the development of HCC in non-cirrhotic patients following the eradication of $\mathrm{HCV}$ with interferon (Belperio et al., 2017).

The clinical importance of OBI includes the possibility of HBV transmission in patients receiving blood transfusion and organ transplantation, especially the liver (Squadrito et al., 2014). The early identification of OBI helps prompt patient management (Kwak and Kim, 2014).

The aim of this study was to evaluate the prevalence of occult Hepatitis B Virus infection in positive Hepatitis C Virus patients on regular hemodialysis.

\section{PATIENTS AND METHODS}

This study was conducted on 100 patients with end-stage renal disease undergoing regular Hemodialysis from the dialysis unit related to the Department of Nephrology, Nasser Institute, Egypt, during the period from July 2017 to January 2018. The study protocol will be approved by the local ethics committee and all patients will give their informed consent prior to the study.

\section{Inclusion Criteria:}

a. On regular HD for at least 6 months.

b. Positive for anti-HCV antibodies.

c. Negative for HBs-Ag.
Exclusion Criteria:

a. Overt HBV infection (HBs-Ag positive).

b. Patients with alcoholic, autoimmune, malignant or metabolic liver diseases.

All the studied patients were subjected to the following:

Clinical assessment (History taking and physical examination) Biochemical assessment: Liver functions (alanine aminotransferase, aspartate aminotransferase and serumalbumin), kidney functions (blood urea and serum creatinine), complete blood counts, calcium, and phosphorus.

Testing for hepatitis B serology was achieved by:

-Hepatitis B surface antigen (HBsAg) by ELISA.

- Total anti-Hepatitis B Core antibody IgG.

- Hepatitis B virus DNA (HBV-DNA) by real time Polymerase chain reaction(PCR): only to do in patients positive for anti-HBc antibody.

Testing for hepatitis C serology was achieved by:

- Hepatitis C antibody by Enzyme Linked Immuno-sorbent Assay (ELISA).

- Hepatitis C virus RNA by PCR.

\section{Statistical Analysis:}

All data were collected, tabulated, and statistically analyzed using the software, statistical package for social science (SPSS) version 17.

- Description of quantitative variables as mean $+\mathrm{SD}$, range and median (IQR). 
- Relationship between parameters was coefficients ${ }^{\circledR}$. analyzed using the Pearson correlation

\section{RESULTS}

Females were $39 \%$ and males were $61 \%$ ) and age ranged between 18-60 with a mean of $39.20 \pm 11.98$ (Table 1).

Table (1): Demographic data distribution of the study group

\begin{tabular}{|c|c|}
\hline Demographic data & Total $(\mathbf{n = 1 0 0})$ \\
\hline Sex & \\
\hline- Female & $39(39.0 \%)$ \\
\hline- Male & $61(61.0 \%)$ \\
\hline Age (years) & $18-60$ \\
\hline- Range & $39.20 \pm 11.98$ \\
\hline
\end{tabular}

There was $8 \%$ positive and $92 \%$ negative $\mathrm{HbCIgG}$ (Table 2).

Table (2): Virology marker of the study group

\begin{tabular}{|c|c|}
\hline Virology report & Total $(n=100)$ \\
\hline $\begin{array}{l}\text { HBs Ag } \\
-\quad \text { Negative }\end{array}$ & $100(100.0 \%)$ \\
\hline $\begin{array}{l}\text { HCV Ab } \\
-\quad \text { Positive }\end{array}$ & $100(100.0 \%)$ \\
\hline $\begin{array}{l}\text { HIV Ab } \\
-\quad \text { Negative }\end{array}$ & $100(100.0 \%)$ \\
\hline $\begin{array}{ll}\text { HCV RNA PCR } \\
-\quad \text { Range } \\
-\quad \text { Median (IQR) } \\
-\quad \text { Mean } \pm \text { SD } \\
\end{array}$ & $\begin{array}{c}10000-4664870 \\
148810(555072.50) \\
498337.1 \pm 835275.36 \\
\end{array}$ \\
\hline $\begin{array}{l}\text { HBcIgG } \\
-\quad \text { Positive } \\
-\quad \text { Negative }\end{array}$ & $\begin{array}{c}8(8.0 \%) \\
92(92.0 \%)\end{array}$ \\
\hline $\begin{array}{l}\text { HBV DNA PCR }(\boldsymbol{n}=\boldsymbol{8}) \\
-\quad \text { Negative } \\
-\quad \text { Positive } \\
-\quad \text { Range }[\text { Mean } \pm \text { SD] }\end{array}$ & $\begin{array}{c}6(75.0 \%) \\
2(25.0 \%) \\
180-700[440.0 \pm 367.7]\end{array}$ \\
\hline
\end{tabular}

IQR: Interquartile range

There was elevation of the mean creatinine and BUN, decreased mean calcium, high PO4 according to ESRD laboratory criteria, high ALT, AST and low albumin and low platelet count according to Hepatitis $\mathrm{C}$ diseased patients laboratory criteria (Table 3). 
Table (3): Laboratory data descriptive of the study group

\begin{tabular}{|l|cc|}
\hline \multicolumn{1}{|c|}{ Laboratory data } & \multicolumn{2}{c|}{ Total $(\mathbf{n = 1 0 0})$} \\
\hline Creatinine(mg/dl) & $3.8-14$ & $(9.53 \pm 2.50)$ \\
\hline BUN $(\mathrm{mg} / \mathrm{dl})$ & $26-98$ & $(56.65 \pm 15.00)$ \\
\hline Ca(mg/dL) & $4.7-12.4$ & $(8.60 \pm 1.20)$ \\
\hline Po4(mg/dL) & $1.9-10.7$ & $(4.59 \pm 1.72)$ \\
\hline AST(U/L) & $5-40$ & $(25.14 \pm 8.33)$ \\
\hline ALT(U/L) & $5-55$ & $(24.89 \pm 9.92)$ \\
\hline Albumin $(\mathrm{mg} / \mathrm{dL})$ & $2-4$ & $(2.99 \pm 0.59)$ \\
\hline Hemoglobin(g/dL) & $6-14.2$ & $(10.13 \pm 1.61)$ \\
\hline WBCs(thousands/cmm) & $2.2-14.2$ & $(7.10 \pm 2.47)$ \\
\hline Platelets(thousands/cmm) & $3.4-388$ & $(191.61 \pm 71.27)$ \\
\hline
\end{tabular}

There was a statistically significant increase mean of occult hepatitis positive according to duration of hemodialysis, compared to occult hepatitis $\mathrm{B}$ negative HCVRNA PCR and ALT (Table 4).

Table (4): Comparison between occult hepatitis B positive and occult hepatitis B negative according to demographic data

\begin{tabular}{|c|c|c|c|}
\hline $\begin{array}{ll}\text { Parameters } & \text { Groups } \\
\end{array}$ & $\begin{array}{c}\text { Ocult Hepatitis B } \\
\text { Positive }(n=2)\end{array}$ & $\begin{array}{c}\text { Ocult Hepatitis B } \\
\text { Negative }(n=98)\end{array}$ & p-value \\
\hline \multicolumn{4}{|l|}{ Demographic data } \\
\hline \multicolumn{4}{|l|}{ Sex } \\
\hline Female & $1(50.0 \%)$ & $38(38.8 \%)$ & 0.747 \\
\hline Male & $1(50.0 \%)$ & $60(61.2 \%)$ & \\
\hline Age (years) & $32.00 \pm 7.07$ & $39.35 \pm 12.04$ & 0.393 \\
\hline \multicolumn{4}{|l|}{ Clinical } \\
\hline $\begin{array}{l}\text { Duration of } \\
\text { Hemodialysis (years) }\end{array}$ & $10.00 \pm 2.83$ & $5.26 \pm 2.87$ & 0.024 \\
\hline \multicolumn{4}{|l|}{ Cause of hemodyalisis } \\
\hline $\mathrm{DM}$ & $1(50.0 \%)$ & $25(25.5 \%)$ & 0.924 \\
\hline HTN & $1(50.0 \%)$ & $51(52.0 \%)$ & \\
\hline NSAIDs abuse & $0(0.0 \%)$ & $4(4.1 \%)$ & \\
\hline $\begin{array}{l}\text { Polycystic kidney } \\
\text { disease }\end{array}$ & $0(0.0 \%)$ & $3(3.1 \%)$ & \\
\hline Unknown & $0(0.0 \%)$ & $15(15.3 \%)$ & \\
\hline HCV RNA PCR & $3197921 \pm 2074580$ & $443244 \pm 717196$ & $<0.001$ \\
\hline \multicolumn{4}{|l|}{ Laboratory data } \\
\hline Creatinine & $9.00 \pm 4.38$ & $9.54 \pm 2.48$ & 0.765 \\
\hline BUN & $63.00 \pm 8.49$ & $56.52 \pm 15.11$ & 0.548 \\
\hline $\mathrm{Ca}$ & $7.45 \pm 0.21$ & $8.62 \pm 1.20$ & 0.173 \\
\hline Po4 & $4.60 \pm 2.26$ & $4.59 \pm 1.72$ & 0.539 \\
\hline AST & $29.50 \pm 14.85$ & $25.05 \pm 8.26$ & 0.458 \\
\hline ALT & $52.50 \pm 3.54$ & $24.33 \pm 9.18$ & $<0.001$ \\
\hline Albumin & $2.35 \pm 0.21$ & $3.00 \pm 0.59$ & 0.126 \\
\hline Hemoglobin & $8.45 \pm 0.07$ & $10.16 \pm 1.61$ & 0.138 \\
\hline WBCs & $6.45 \pm 1.20$ & $7.12 \pm 2.49$ & 0.707 \\
\hline Platelets & $228.00 \pm 0.00$ & $190.87 \pm 71.81$ & 0.469 \\
\hline
\end{tabular}




\section{DISCUSSION}

HBV infection is a major health concern due to its widespread prevalence, with 350,000 million infected individuals, worldwide (Raimondo et al., 2019). Anti$\mathrm{HBc}$ constitutes the first antibody response to $\mathrm{HBV}$ infection, and its detection in the serum may denote acute or chronic infection. Patients remain antiHBc-positive after recovery, and this antibody therefore serves as the only serologic marker for $\mathrm{HBV}$ during the window period of infection. As a result, this marker is considered one of the most valuable serological markers for the diagnosis of OBI (Urbani et al., 2010; Ocana et al., 2011 and Kang et al., 2014). The detection of HBV DNA is considered the most definitive diagnostic tool for the detection of occult hepatitis infection. In our study, we used nested PCR because this method is simple and accurate, easy to interpret, can detect even very low amounts of viral DNA and has been previously applied on a wide scale for the detection, genotyping and phylogenetic analysis of HBV (Albuquerque et al., 2012; Sun et al., 2012 and Panigrahi et al., 2013).

In our research, the occurrence rate of occult HBV infection in hemodialysis patients infected with HCV was specified. The $\mathrm{HBcIgG}$ was found in $8 \%$ of those patients and solely $2 \%$ of them were HBV PCR positive.

Our analysis demonstrated that occult hepatitis B Viral infection was uncommon in hemodialysis patients infected with $\mathrm{HCV}$ regardless of age, sex. However, the amino-transferases levels and the period of dialysis might play a significant role in increasing occult hepatitis B Viral infection.

In an exceedingly survey in central Greece, the occurrence rate of occult HBV reported to be $0.9 \%$ (Mina et al., 2010). Study of Motta et al., (2010), on HBs Ag ve HD patients stated that the occurrence of HBV-DNA was in $15 \%$ of the group tested.

In alternative studies, the occurrence rate of occult HBV reported to be in Spain $58 \%$, Canada $3.8 \%$, Italia $0 \%$, Turkey $0 \%$, Egypt $4.1 \%$ (Abu El Makarem et al., 2012) and in Brazil was reported to be $1.5 \%$ (Albuquerque et al.,2012).

The higher occurrence rate of segregated anti-HBc is found in endemic communities such as South-East Asia, Greece and lastly, sub-Saharan Africa. HBV-DNA is found in $10 \%$ of subjects with anti-HBc alone, with a range between $0 \%$ and $22.8 \%$, relying on the geographic region and population elite (Pondé et al., 2010).

Findings of our study are similar to some previous reports, and are also dissimilar to some previous reports. These contradictions within the rate of occult HBV infection in HD patients may mirror the varied occurrence rate of hepatitis $B$ Viral infection in several communities, whereas Iran is reported as having low endemicity for HBV infection, and most of studies with similar results were present in states with low endemicity of hepatitis B Viral infection and most of the high rates of occult hepatitis B Viral infection were shown in countries with high or intermediate endemicity of $\mathrm{HBV}$ infection. 
Other possible explanations of those discrepancies within the rate of occult hepatitis B Viral infection in HD patients embrace sensibility of biology techniques, size and virological features of the patient groups and therefore the clinical specimens and samples choice criteria for the HBV-DNA tests.

In our study, the patients were elite for HBV-DNA assay if they had the positive anti-HBc result, and HBV DNA wasn't checked for anti- $\mathrm{HBc}$ negative patients, this may be mention as the main limitation of this study.

\section{CONCLUSION}

OBI was more prevalent among chronic $\mathrm{HCV}$ patients than HD patients, with 8 positive $\mathrm{HBcIgG}$ cases of 100 patients, 2 cases out of 8 positive $\mathrm{HBcIgG}$ were tested positive for HBV DNA. However, more precise assessment of this infection requires regular patient followup using HBV DNA detection methods.

\section{REFERENCES}

1. Abu El Makarem MA, Abdel Hamid M, Abdel Aleem A, Ali A, Shatat M and Sayed D (2012): Prevalence of occult hepatitis $B$ virus infection in hemodialysis patients from egypt with or without hepatitis $\mathrm{C}$ virus infection. Hepat Mon., 12:253-8.

2. Aghakhani A, Banifazl M, Kalantar E, Eslamifar A, Ahmadi $F$ and Razeghi $\mathbf{E}$ (2010): Occult hepatitis B virus infection in hemodialysis patients with isolated hepatitis B core antibody: a multicenter study. TherApher Dial., 14(3):349-53.

3. Albuquerque AC, Coelho MR, Lemos MF and Moreira RC (2012): Occult hepatitis B virus infection in hemodialysis patients in Recife, State of Pernambuco, Brazil. Rev Soc Bras Med Trop., 45: 558-562.
4. Amer FA, Gohar M and Yousef M (2015): Epidemiology of hepatitis $\mathrm{C}$ virus infection in Egypt. Int J Trop Dis Health., 7(7):119-31.

5. Belperio PS, Shahoumian TA, Mole LA and Backus LI (2017): Evaluation of hepatitis B reactivation among 62,920 veterans treated with oral hepatitis C anti-virals. Hepatology, 66: 27-36.

6. Datta S, Chatterjee S, Veer V andChakravarty R (2012): Molecular biology of the hepatitis Bvirus for clinicians. J. Clin. Exp. Hepatol., 2(4):353-65.

7. Inoue T, Tanaka Y (2016): Hepatitis B virus and its sexually transmitted infection-an update. Microbial Cell., 3(9):420-45.

8. Kang SY, Kim MH and Lee WI (2014): Occult hepatitis B virus infection in Korean patients with isolated anti-HBc. Arch Virol., 159:227-233.

9. Kwak M-S and Kim YJ (2014): Occult hepatitis B virus infection. World J.Hepatol., 6 (12):860-476.

10. Mina P, Georgiadou SP, Rizos C, Dalekos GN andRigopoulou EI (2010): Prevalence of occult hepatitis B virus infection in haemodialysis patients from central Greece. World J. Gastroenterol., 16:225-31.

11. Motta JS, Mello FC, Lago BV, Perez RM, Gomes SA and Figueiredo FF (2010): Occult hepatitis B virus infection and lamivudineresistant mutations in isolates from renal patients undergoing hemodialysis. J. Gastroenterol Hepatol., 25:101-6.

12. Ocana S, Casas ML, Buhigas I and Lledo JL (2011): Diagnostic strategy for occult hepatitis B virus infection. World J.Gastroenterol., 17: 1553-1557.

13. Panigrahi R, Biswas A, De BK, Chakrabarti $S$ and Chakravarty $R$ (2013): Characterization of antiviral resistance mutations among the Eastern Indian Hepatitis B virus infected population. Virol J., 10: 56-70.

14. Pondé RA, Cardoso DD and Ferro MO (2010): The underlying mechanisms for the 'anti-HBc alone' serological profile. Arch Virol., 155:149-58. 
15. Raimondo G, Allain JP, Brunetto MR, Buendia MA, Chen DS and Colombo $M$ (2019): Statements from the Taormina expert meeting on occult hepatitis B virus infection. Updated Journal of Hepatology., 71 : 397-408.

16. Raimondo G and Pollicino T (2016): Occult HBV infection. Hepatitis B virus in human diseases. Springer USA., 277-301.

17. Squadrito $G$, Spinella $R$ andRaimondo $G$ (2014): The clinical significance of occult HBV infection. Ann Gastroenterol., 27(1):15-4.

18. Sun S, Zhou H, Zhou B, Hu Z, Hou J and Sun J (2012): Sensitivity and specificity of nested PCR pyro sequencing in hepatitis B virus drug resistance gene testing. Nan Fang Yi Ke Da Xue Xue Bao., 32: 610-613.

19. Urbani S, Fagnoni F, Missale $G$ and Franchini $M$ (2010): The role of anti-core antibody response in the detection of occult hepatitis B virus infection. Clin Chem Lab Med., 48: 23-29. 
فيروس بي الخفي في مرضي الغسبل الكلوي المصابين

عبدالعزيز ممدوح محمد عبدالعزيز محمد بربش برئ

قسم الباطنة العامة، كلية الطب، جامعة الازهر

E-mail: abdelaziz.berbesh@yahoo.com

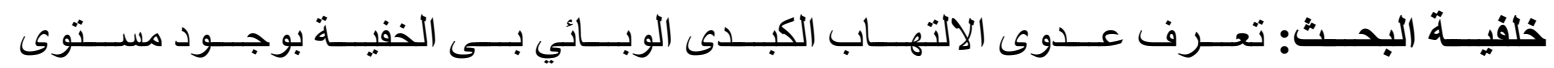

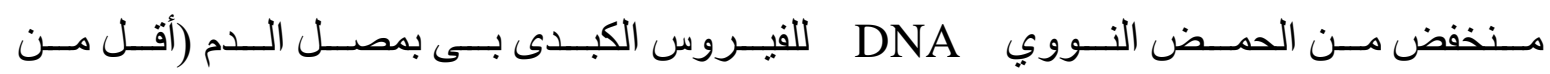

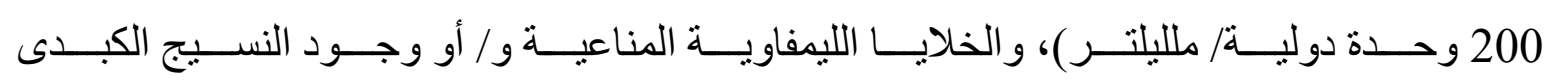

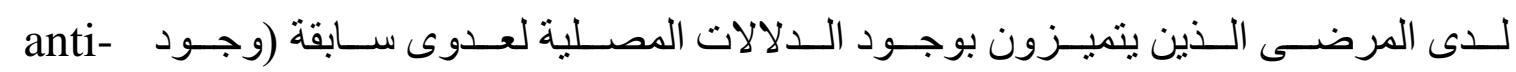

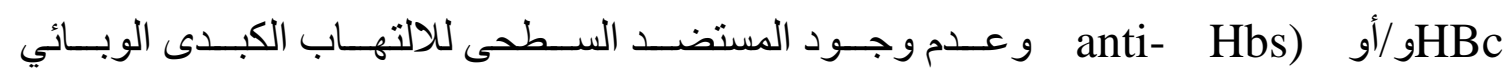
ب بى بمصل الدم.

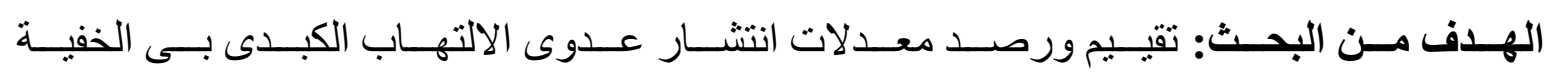
بين مرضى الغسيل الكلوى المصابين بالالتهاب الكبدى الوبائي سى.

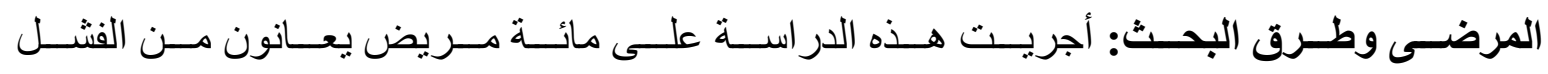

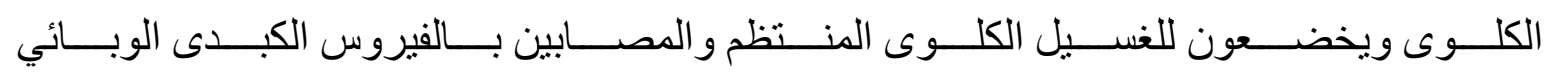

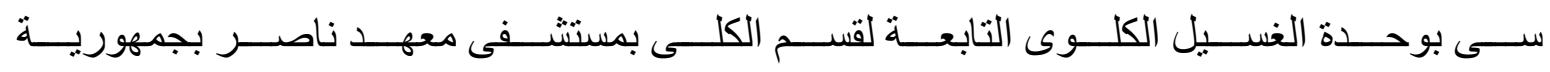
مصر العربية فى الفترة من يوليو حتى يناير 2018.

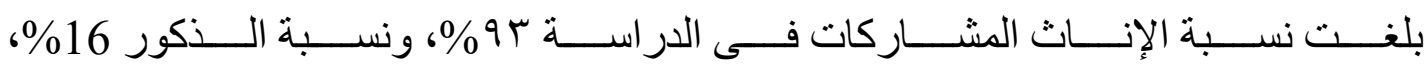

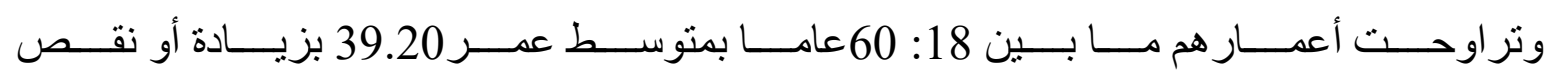

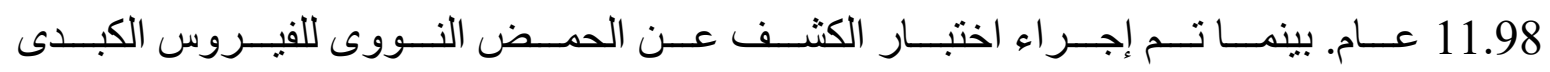

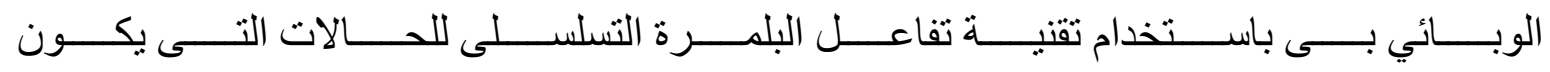
اختبار Anti-HBc antibody إيجابيا فقط.

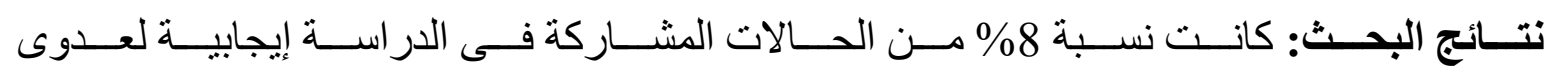

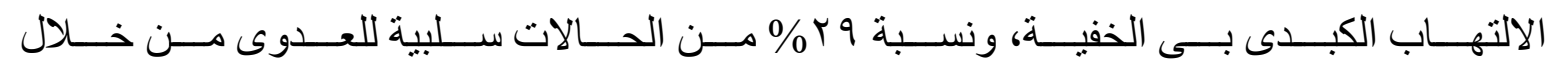

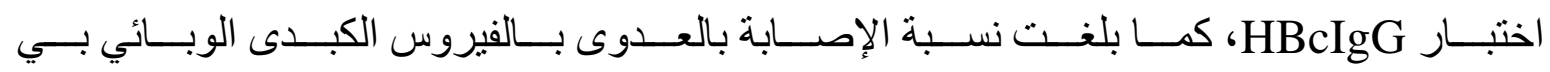
r \% فقط عن طريق تفاعل البلمرة التسلسلي للحمض النووى للفيروس. 


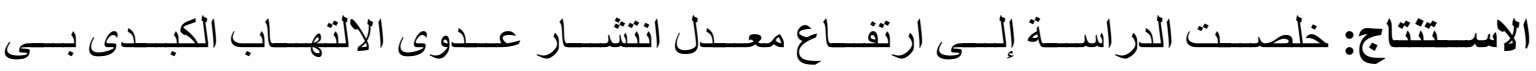

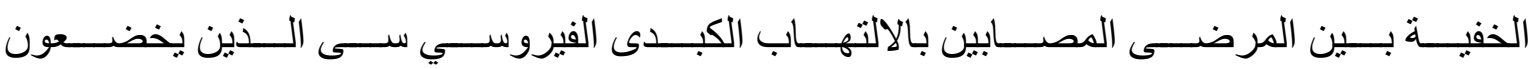

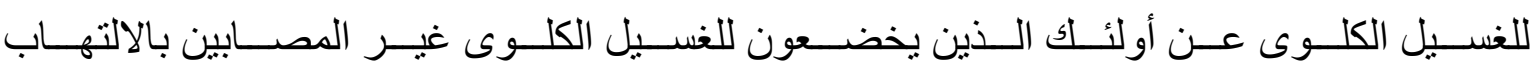

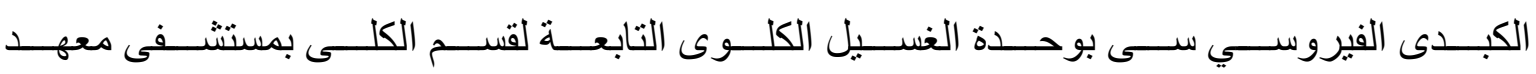

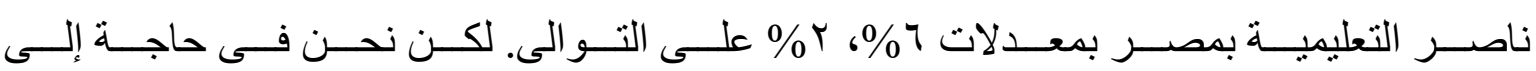

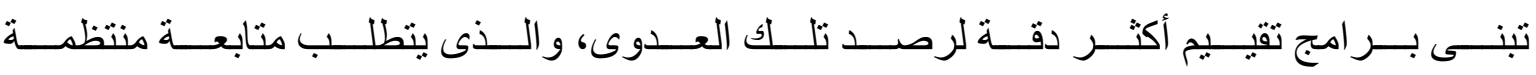

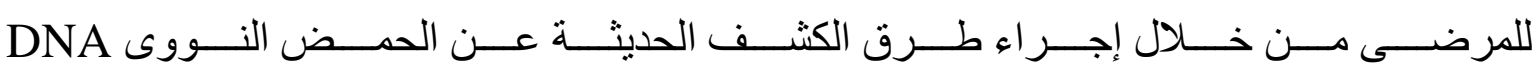
للفيروس الكبدى الوبائي بى. الكلمات الدالة : فيروس بى الخفى - الغسيل الكلوى . 